\title{
The effect of anxiety on postoperative pain expectation and opioid consumption in modified radical mastectomy operations
}

\section{Modifiye radikal mastektomi operasyonlarında anksiyetenin postoperatif ağrı beklentisi ve opioid tüketimi üzerine etkisi}

\author{
Erbin Kandemir $^{1}$ (D), Tuğba Aşkın ${ }^{1}$ (D), Tünay Kandemir ${ }^{1 *}$ (D), Gonca Oğuz Tuncel ${ }^{1}$ (D), Süheyla Ünver ${ }^{1}$ \\ ${ }^{1}$ Dr. Abdurrahman Yurtaslan Onkoloji Eğitim ve Araştırma Hastanesi, Ankara, Turkey \\ * Corresponding author: Tünay Kandemir E-mail: tunaykandemir@gmail.com ORCID: 0000-0002-5656-0352 \\ Received: 16 September 2018 Accepted: 7 January 2019
}

\begin{abstract}
Aim: Breast cancer is the most common cancer in women and is the second most cause of cancer associated death. After diagnosis is made, emotional distress, anxiety and depression occurs in $35-38 \%$ of women. High anxiety levels prior to operation increases the sensitivity and expectation of the patients towrads pain, influencing the severity of postoperative pain. The aim of the present study was to evaluate the effect of preoperative anxiety on postoperative pain expectation, postoperative pain and opioid consumption in patients undergoing modified radical mastectomy.
\end{abstract}

Material and Method: 60 female patients between the ages of 18-65 were included in the present study. Preoperative anxiety was evaluated using State Trait Anxiety Inventory (STAI) and postoperative pain expectation using Visual Analog Scale (VAS). STAI1 test was administered at preoperative visit, preoperatively and postoperative 6th hour while STAI2 was administered at preoeprative visit. Demographic characteristics were questioned. Postoperative pain levels and overall morphine consumption were recorded.

Results: Postoperative STAI1 values were significantly lower than preoperative visit and preoperative STAI1 values $(p=0.002$ - $p=0.004$ ). Weak but statistically significant correlation was shown between preoperative visit STAI1 and STAI2 values. A statistically significant but weak positive relation was found betwen STAI1 preoperative and STAI1 postoperative 6th hour values and postoperative VAS $(p=0.030 ; \mathrm{rho}=0.280 ; \mathrm{p}=0.003 ; \mathrm{rho}=0.378$ ). Median postperative pain expectation was found to be $6.0(\min =3.0 ; \max =10.0)$.

Conclusion: In the present study, it was demonstrated that high preoparetive anxiety scores are associated with increased postoperative pain level anxiety stimulations may potentiate pain, by exerting pain like effect via psychological system. It is our suggestion that, in special patient groups in which anxiety levels are high, such as breast cancer patients, planning postoeprative pain management after determining preoperative anxiety level and other risk factors will increase patient satsisfaction and the efficacy of analgesia.

Keywords: modified radical mastectomy, anxiety, expectation of pain 


\section{öz}

Amaç: Meme kanseri kadınlarda en sık görülen ve ikinci sırada yer alan kanser ilişkili ölüm sebebidir. Tanı konulduktan sonra hastaların \%35-38'inde emosyonel distres, anksiyete ve depresyon görülür. Ameliyat öncesi yüksek anksiyete, hastanın ağrıya karşı olan hassasiyetini ve beklentisini arttırarak postoperatif ağrının şiddetini etkileyebilir. Bu çalışmadaki amacımız modifiye radikal mastektomi operasyonu uygulanan hastalarda preoperatif anksiyetenin postoperatif ağrı beklentisi, postoperatif ağrı ve opioid tüketimi üzerine etkisinin değerlendirilmesidir.

Gereç ve Yöntem: Çalışmaya 18-65 yaş arası 60 kadın hasta dahil edildi. Preoperatif anksiyete Sürekli Durum Anksiyete Envanteri (STAI), postoperatif ağrı beklentisi Visüel Analog Skala (VAS) kullanılarak değerlendirildi. STAI1 testi preoperatif vizit, preoperatif, postoperatif 6. saatte, STAI2 ise preoperatif vizitte uygulandı. Demografik özellikler sorgulandı. Hastaların postoperatif ağrı seviyeleri ve toplam morfin tüketimleri izlenerek kaydedildi.

Bulgular: Postoperatif STAI1 değerleri, preoperatif vizit ve preoperatif STAI1'den anlamlı düzeyde düşüktü ( $p=0,002$ $p=0,004)$. Preoperatif vizit STAI1 ile STAI2 arasında istatistiksel olarak anlamlı pozitif zayıf korelasyon olduğu gösterildi. STAI1 preoperatif ve STAI1 postoperatif 6 . saat ile postoperatif VAS arasında istatistiksel olarak anlamlı pozitif zayıf bir ilişki olduğu belirlendi ( $p=0,030$; rho=0,280; $p=0,003$; rho=0,378). Operasyon sonrası postoperatif ağrı beklentisi ortancası 6,0 (min=3,0; maks $=10,0$ ) olarak bulundu.

Sonuç: Çalışmamızda preoperatif yüksek anksiyete skorlarının artmış postoperatif ağrı düzeyi ile ilişkili olduğu gösterildi. Anksiyete uyarıları psikolojik sistem üzerinden ağıı benzeri etkiler yaparak ağrıyı potansiyelize edebilir. Meme kanseri gibi anksiyetenin yüksek olduğu özellikli hasta gruplarında, preoperatif anksiyete düzeyi ve diğer risk faktörleri belirlendikten sonra postoperatif ağıı tedavisi planının yapılmasının hasta memnuniyeti ve analjezi etkinliğini arttıracağını düşünüyoruz.

Anahtar kelimeler: modifiye radikal mastektomi, anksiyete, ağrı beklentisi

\section{INTRODUCTION}

Breast cancer is the most common cancer in women and second cause of cancer associated death [1]. As breast cancer, in addition to being the most common cancer in women, threatens an organ symbolizing femininity and sexuality, so far it has been the cancer type which has been investigated most comprehensively in terms of its psychological and psycho-social aspects [2,3]. Surgical intervention that will be made following diagnosis is a source of stress for the patient. Operation, which is usually perceived as the loss of an organ, exerts negative impact on body image, self confidence and psychological status of the patients and their social relations [4].

After the diagnosis of breast cancer is made, emotional distress, anxiety and depression occurs in 35-38\% of the patients [5]. Anxiety stimulations may potentiate pain by exerting pain like effects via psychological system. Pain is influenced from psychological, sensory and emotional state and cognitive, sociocultural and behavioral factors [6]. In these patients, unlike other patients experiencing postoperative pain, high anxiety levels prior to operation may influence the severity of postoperative pain by increasing the sensitivity and expectation of the patient towards pain $[7,8]$.

In postoperative pain management, the focus has been on only phramacothetapy and its routes of administration and psychosocial and behavioral factors have been commonly neglected. In spite of the development of efficient treatment methods, $30-80 \%$ of the patients experience moderate or severe acute pain in postoperative period $[9,10]$. Recently, when characteristics such as inadequate response to drugs and increased sensitivity to pain have been investigated, clinical predictors of postoperative pain have been evaluated together with experimental pain models [11]. Vivian et al. [12], in their study, defined preoperative pain, anxiety, age and type of surgery as important predictors of postoperative pain. Aouad et al. [11] suggested that preoperative anxiety scores and postoperative pain expectation are independent factors affecting morphine consumption after hysterectomy operations, and in another study, it was demonstrated that patients expected moderate or severe pain in postoperative period and that real pain experience was consistent with preoperative expectations [13]. 
The aim of the present study was to evaluate the effect of preoperative anxiety on postoperative pain expectation, postoperative pain and opioid consumption in patients who are undergoing modified radical mastectotmy.

\section{MATERIAL AND METHOD}

The present study was carried out in Anesthesia and Reanimation clinic of Dr. Abdurrahman Yurtaslan Ankara Oncology Training and Investigation Hospital between February 2016-May 2016 with local Ethics Committee approval no 204 and dated 17.02. 2016.

60 female patients between the ages of 18-65 who were planned to undergo modified radical mastectomy with the breast cancer diagnosis who were in ASA (American Society of Anesthesiologists) group 1-3 were included in the present study. Patients who have severe cardiac, renal, hepatic and pulmonary failure, those with major hearing problems and communication problems, who have chronic pain, the ones who use NSAIDs or opioids, and who have psychological disease history or brain damage or receive psychological treatment were excluded from the study. The study was carried out with verbal and written consent of all patients.

At the preoperative visit, patients were administered State Trait Inventory Index 1 (STAI 1) and State Trait Inventory Index 2 (STAI 2) and postoperative pain expectation was evaluated with Visual Analog Scale (VAS, 0: no pain, 10: very severe pain) and results were recorded. Patients were informed about patient controlled analgesia (PCA) device that will be used for the control of postoperative pain. STAI 1 test was repeated on the morning of operation and at postoperative 6 th hour.

All patients included in the study were administered routine premedication, general anesthesia, and postoperative PCA methods. Prior to operation, premedication was carried out with 0.02-0.03 mg kg-1 iv midazolam. After patients were transferred to operating theater, anesthesia induction was performed with $2 \mathrm{mg} \mathrm{kg}-1$ propofol, $2 \mu \mathrm{g} \mathrm{kg}-1$ fentanyl, 1 $\mathrm{mg} \mathrm{kg}-1$ lidocain and $0.5 \mathrm{mg} \mathrm{kg}-1$ rocuronium and subsequently general anesthesia maintenance was made with $60 \% \mathrm{~N}_{2} \mathrm{O} / 40 \% \mathrm{O}_{2}$ and $2 \%$ of sevoflurane. All patients were ex-tube in operating room and $5 \mathrm{mg}$ intravenous morphine was administered 5 minute before exubation.

All patients were connected to PCA device after operation in post anesthesia care unit. PCA was programmed with morphine at bolus $1 \mathrm{mg}$, lock time $5 \mathrm{~min}$, and at 4-hour limit of $30 \mathrm{mg}$ and without continuous infusion. At postoperative $0,2,6,12$, and 24 hours, patient pain was evaluated with VAS scale. When VAS was $\geq 4,5 \mathrm{mg}$ intrevenous (iv) morphin
Table 1. Age, weight, length and ASA classes of patients [mean $\pm \mathrm{SD}, \mathrm{n}, \%$, median (min-maks)]

\begin{tabular}{|c|c|}
\hline Age (year) & $48.0 \pm 9.6$ \\
\hline Weight $(\mathbf{k g})$ & $69.9 \pm 12.4$ \\
\hline Length $\mathbf{( c m )}$ & $159.6 \pm 5.5$ \\
\hline ASA (1/2)* & $7(11.7) / 53(88.3)$ \\
\hline
\end{tabular}

*ASA: American Society of Anesthesiologists

bolus dose was administered. Overall morphine consumption, and the number of demanded and administered boluses were monitored and recorded. At the end of the study, patient satisfaction was evaluated using a 5-degree scale (not satisfied, slightly satisfied, satisfied, very satisfied, excellent).

\section{Statistical Analyses}

In the evaluation of Postoperative VAS, demanded morphine, administered morphine, overall morphine and differences in values of STAI1 at preoperative visit, preoperatively and postoperative 6th hour Friedmann twoway variance analysis was used. When difference was found between different measurement times, Bonferroni correction dual comparison results were investigated.

In the examination of the relation between STAI 1 Preoperative visit, STAI 1 Preoperative, STAI 1 Postoperative 6th hour measurements and STAI 2 Preoperative visit values, Spearman's Rho correlation test was used. In the evaluation of STAI 1 preoperative visit, STAI 1 preoperative, STAI 1 postoperative 6th hour, STAI 2 preoperative visit and postoperative VAS pain expectation variables in the context of demographic information, among Independent two sample t test, Mann Whitney $U$ test and Kruskall Wallis test whichever was suitable was used.

For statistical analyses and evaluations, IBM SPSS Statistics 21.0 (IBM Corp. Released 2012. IBM SPSS Statistics for Windows, Version 21.0. Armonk, NY: IBM Corp.) program was used. Statistical hypotheses were evaluated at Type I error level $\mathrm{a}=0.05$.

\section{RESULTS}

Age, weight, ASA, diagnosis and operation duration of the patients included in the study are demonstrated in Table 1. Mean age of the patients was $48.0 \pm 9.6$ and median value of weight, length, diagnosis and operation duration variables were respectively $68 \mathrm{~kg}, 160 \mathrm{~cm}, 30$ days and 120.0 minutes.

After operation, postoperative pain expectation (VAS) median value was found to be 6.0 ( $\mathrm{min}=3.0 ; \mathrm{max}=10.0)$. STAI 1 and STAI 2 variables at different measurement times were shown in Table 2 . Median value of STAI 1 variable at 
Table 2. STAI 1 and STAI 2 variables at different measurement times, postoperative pain expectation (VAS)¥

\begin{tabular}{|c|c|c|c|c|c|}
\hline \multirow{3}{*}{ Variables } & \multicolumn{3}{|c|}{ Measurement Times } & \multirow{2}{*}{\multicolumn{2}{|c|}{ Test statistics * }} \\
\hline & \multirow{2}{*}{$\begin{array}{l}\text { Preop visit } \\
\text { mean } \pm \text { SD }\end{array}$} & \multirow{2}{*}{$\begin{array}{c}\text { Preop } \\
\text { mean } \pm \text { SD }\end{array}$} & \multirow{2}{*}{$\begin{array}{c}\text { Postop 6. hour } \\
\text { Median (min; max) }\end{array}$} & & \\
\hline & & & & $\chi^{2}$ & $\mathbf{P}$ \\
\hline STAI 1 & $43.13 \pm 8.7$ & $43.0 \pm 9.6$ & $38.5(22 ; 65)$ & 15.851 & $<0.001$ \\
\hline STAI 2 & $45.7 \pm 7.3$ & - & - & & \\
\hline Postop & expectation & & $6.0(\min =3.0$ & & \\
\hline
\end{tabular}

*Friedman two-way variance analysis, STAI: State-Trait Anxiety Invantory. ¥ VAS: Visual Analog Scale

Table 3. The relation between STAI variables and demanded, administered and overall morphine and median postoperative VAS*

\begin{tabular}{|c|c|c|c|c|c|c|c|c|}
\hline & \multicolumn{2}{|c|}{ Demanded morphine } & \multicolumn{1}{c|}{ Administered morphine } & \multicolumn{2}{c|}{ Overall morphine } & \multicolumn{2}{c|}{ Median VAS } \\
\cline { 2 - 9 } & Rho & $\mathbf{P}$ & Rho & $\mathbf{P}$ & Rho & $\mathbf{P}$ & Rho & P \\
\hline STAI 1 Preop visit & 0.164 & 0.212 & 0.128 & 0.328 & 0.154 & 0.239 & 0.224 & 0.086 \\
\hline STAI 1 Preop & 0.058 & 0.662 & 0.027 & 0.835 & 0.039 & 0.770 & 0.280 & $\mathbf{0 . 0 3 0}$ \\
\hline STAI 1 Postop 6. Hour & 0.010 & 0.938 & -0.033 & 0.804 & 0.055 & 0.679 & 0.378 & $\mathbf{0 . 0 0 3}$ \\
\hline STAI 2 Preop visit & -0.056 & 0.672 & -0.005 & 0.970 & -0.046 & 0.728 & 0.066 & 0.614 \\
\hline
\end{tabular}

*Spearman rho correlation test

Table 4. The relation between postoperative pain expectation and other variables*

\begin{tabular}{|c|c|c|}
\hline \multirow{2}{*}{} & \multicolumn{2}{|c|}{$\begin{array}{c}\text { Postoperative } \\
\text { Pain expectation }\end{array}$} \\
\cline { 2 - 3 } & Rho & P \\
\hline STAI 1 Preoperative visit & -0.129 & 0.326 \\
\hline STAI 1 Preoperative & -0.212 & 0.104 \\
\hline STAI 2 Preoperative visit & -0.008 & 0.950 \\
\hline 24. hour administered morphine & 0.048 & 0.717 \\
\hline 24. hour demanded morphine & 0.086 & 0.515 \\
\hline 24. hour overall morphine & 0.079 & 0.548 \\
\hline Median postoperative VAS & -0.098 & 0.455 \\
\hline
\end{tabular}

preoperative visit, preoperatively and at $6 \mathrm{~h}$ hour postoperatively was established to be respectively $44 ; 43.5$ and 38.5. It was determined that STAI 1 values displayed differences between preoperative visit, preoperative and 6 th hour measurement times $(p<0.001)$. The difference between preoperative visit and preoperative STAI 1 values was not significant $(p=1.000)$, while postoperative STAI 1 values were significantly lower than preoperative visit and preoperative STAI 1 values (respectively, $p=0.002$ and $\mathrm{p}=0.004)$. STAI 2 preoperative visit median value was found to be 46 (min-max: 29-64).

It was demonstrated that there was weak but statistically significant correlation between Preoperative visit STAI 1 and STAI 2 ( $p=0.011$; rho=0.327). Other relations between STAI 1 and STAI 2 measurements were not found to be significant $(p>0.05)$.

A weak but statistically significant positive relation was found between STAI 1 preoperative and STAI 1 postoperative 6 th hour values and median postoperative
Table 5. Distribution of satisfaction status

\begin{tabular}{|c|c|}
\hline \multicolumn{2}{|c|}{ Degree of satisfaction } \\
\hline Not satisfied & - \\
\hline Slightly satisfied & - \\
\hline Satisfied & $8(13.3)$ \\
\hline Very satisfied & $28(46.7)$ \\
\hline Perfect & $24(40.0)$ \\
\hline
\end{tabular}

VAS value (respectively $\mathrm{p}=0.030 ;$ rho $=0.280 ; \mathrm{p}=0.003$; rho $=0.378$ ) (Table 3). No statistically significant relation was found between STAI 1 values and STAI 2 value and morphine demanded, administered and consumed overall morphine at 24 hours ( $p>0.05)$.

It was established that postoperative pain expectation (VAS) had no significant relation with, STAI 1 and STAI 2 values, demanded, administered and overall morphine amounts, postoperative median VAS value ( $p>0.05$ ) (Table 4).

Satisfaction degree of patients included in the present study was demonstrated in Table 5. It was established that 28 $(46.7 \%)$ patients were very satisfied with postoperative analgesia.

\section{DISCUSSION}

In the present study, it was demonstrated that in patients undergoing modified radical mastectomy operation, higher preoperative anxiety scores increased postoperative pain level. A positive relation was found between preoperative and postoperative 6 . hour STAI 1 values and postoperative pain scores. However, no relation was found between postoperative pain expectation evaluated at preoperative 
visit and anxiety, postoperative pain and opioid consumption.

Postoperative pain is an acute pain that starts with surgical trauma and gradually decreases with tissue healing [14]. Pain is a sensory and emotional experience that is influenced from physiological, sensorial, cognitive, sociocultural and behavioral factors. In spite of the developments in pain evaluation and treatment methods, $30-80 \%$ of patients experience moderate or severe acute pain during postoperative period $[9,10]$. Inadequate postoperative pain management has a negative impact on the course of the disease and may lead to the development of chronic pain. Postoperative chronic pain has been reported in rates ranging between $20 \%$ [15] and 68\% [16]. It has been reported that preoperative anxiety enhanced the pain of acute mastectomy [17] and that in patients with postmastectomy pain lasting for $\geq 3$ months after operation, anxiety level was higher than that in patients without pain [10].

Anxiety stimulation my potentiate pain byexertin pain like effects via psychological system [7]. In adults, the prevalence of anxiety before surgery varies between $11 \%-80 \%$. In women and cases diagnosed with cancer, higher anxiety levels have been reported [18,19]. 20-35\% of female breast cancer patients experience anxiety at a certain period of their disease process, independent of the stage of disease and treatment status [20]. In operation period, anxiety of clinical significance arises in 33\% of patients [21].

STAI (State-Trait Anxiety Inventory) employed prior to operation for measurement of anxiety has been shown as gold standard in the literature for this purpose [22]. It is usually the trait anxiety form of STAI test which is preferred. In 60 patients included in the present study mean preoperative visit anxiety score was $43.1 \pm 8.7$, mean preoperative anxiety score was 43.9.6, median postoperative 6 . hour anxiety score was 38.5 , and mean anxiety score according to preoperative STAI-2 scale was 45.7 \pm 7.3 . STA1 value measured at postoperative 6 th hour was found to be significantly lower than those measured at other time points. This was thought to be associated with efficient postoperative analgesia obtained by PCA method and with the termination of anxieties regarding.

In cancer patients, anxiety is at the highest level at the stage of diagnosis, in preoperative period, when starting a new treatment, while waiting for results of investigations and $i$ the likelihood of recurrence [23]. Similarly, in the present study, anxiety levels were found to be higher prior to surgical treatment. Correlation between preoperative STAI 1 (trait anxiety) and STAI 2 (state anxiety) was established to be statistically significant, suggesting that individuals reporting higher state anxiety levels may perceive many conditions as more threatening and display anxiety behaviors at a higher level than those with lower state anxiety levels.

There are publications indicating that preoperative pain or depression increases postoperative pain and opiod consumption [7,24,25]. In these studies, there are methodological differences such as evaluation time of anxiety levels, type of surgery, age group, and the method of administered post operative analgesia. There are few studies investigating the relation between anxiety, pain expectation and experienced post operative pain [13]. In the present study, the relation between anxiety scores measured at preoperative vistit, and preoperativel and postoperative 6th hour and expectation of pain, postoperative pain and opioid consumption. While a positive relation was found between preoperative and postoperative 6 . hour STAI 1 values and postoperative pain scores, no relation was found between overall opioid consumption and anxiety. Factors such as PCA protocol used, and PCA limit added for security reasons may be influential on overall morphine consumption.

Similarly, in the study of Kain et al. [26], the relation between peroperative and postoperative trait anxiety and postoperative pain was demonstrated. It was reported that state anxiety had no direct effect on postoperative pain, while trait anxiety is a marked predictor of postoperative pain. They have also proposed that implementation of strategies that will decrease anxiety in perioperative period, will exert a positive impact on the pain response in postoperative period. It was shown by Ali et al. [27] that in laparoscopic surgical interventions, in patients with low level of anxiety, postoperative pain and analgesic consumption decreased, in addition to shortening of extubation time, making recovery from anesthesia more rapid. In the study of Özalp et al. [7], it was reported that in breast surgery, peroperative emotional factors have an ostive relation with postoperative pain and opioid consumption and stressed that the relation between PCA methods used and postoperative pain and depression should be investigated. In the present study, trait anxiety levels of patients were evaluated in postoperative period as well. It was established that high postoperative anxiety levels increased pain scores. High anxiety levels enhance the sensitivity of person to pain and pain perception. It was established that the relation between increased pain attitude and trait anxiety is associated with state anxiety 
status. However, it was also reported that although state anxiety may be influential on pain perceition, trait and state anxiety exert significant effect in combination [28].

Recently, when characteristics such as inadequate response to drugs, or increased sensitivity to pain are investigated, along with experimental pain models, clinical predictors of postoperative pain have also been investigated [11]. It was suggested by Aouad et al. [11] that preoperative anxiety scores and postoperative pain expectation are independent factors influencing morphine consumption following hysterectomy operations. In the study of Svensson et al. [13], investigating the effect of postoperative pain expectation and real pain experience on patients satisfaction, it was demonstrated that the majority of patients expected moderate or severe postoperative pain and that preoperative expectations were consistent with postoperative experience. In the present study, median postoperative pain expectation was established to be 6.0 ( $\min =3.0 ; \max =10.0$ ). When postoperative pain (VAS) values were investigated, it was observed that the pain experienced was less than the pain expected. It was thought that this may be associated with the efficacy of PCA method we used in pain management. PCA increases the quality of analgesia while providing efficient drug titration and decreases the indience of side effects such as respiratory depression [8,29]. It is thought that participation of the patient in his/her pain control decreases anxiety, accelerates recovery and enhances patient satisfaction [8]. Likewise, in the present study, patient satisfaction was found to be high. No serious side effcts occurred with the morphine used in PCA administration.

\section{CONCLUSION}

In the present study, it was demonstrated that in patients undergoing modified radical mastectomy, high preoperative anxiety scores increase postoperative pain level. A positive relation was found between STAI 1 values measured preoperatively and at 6th hour postoperatively and postoperative pain scores. No relation was found between postoperative pain expectation evaluated at preoperative visit and postoperative pain and morphine consumption.

Anxiety stimulants may potentiate pain byexertin pain like effects via psychological system. It is our suggestion that, in special patients groups in which anxiety is high such as breast cancer, planning pain management after determining anxiety level and other risk factors and addition of methods that will decrease perioperative anxiety to treatment will increase patient management and the efficacy of anesthesia.

\section{DECLARATION OF CONFLICT OF INTEREST}

The authors received no financial support for the research and/or authorship of this article. There is no conflict of interest.

\section{REFERENCES}

1. Stewart W, Wild CP. World Cancer Report 2014 - 28 Jan 2014 B. International Agency for Research on Cancer. Lyon: IARC Publications.

2. Gagnon P, Massie MJ, Holland JC. The woman with breast cancer: Psychosocial considerations. Cancer Bulletin 1993; 45: 538-42.

3. Baider L, Andritsch E, Uziely B, Ever-Hadani P, Goldzweig G, Hofmann G, et al. Do different cultural settings affect the psychological distress of women with breast cancer? A randomized study. Eur J Cancer Care (Engl) 2003; 12: 263-73.

4. Özkan S, Alçalar N. Psychological responses to the surgical treatment of breast cancer. J Breast Health 2009; 5: 60-3.

5. Mehnert A, Koch U. Prevalence of acute and posttraumatic stress disorder and comorbid mental disorders in breast cancer patients during primary cancer care: a prospective study. Psychooncology 2007; 16: 181-8.

6. Tütüncü R, Günay H. Chronic pain, psychological factors and depression. Dicle Medical J 2011; 38: 257-62.

7. Özalp G, Sarıoğlu R, Tuncel G, Aslan K, Kadıoğulları N. Preoperative emotional states in patients with breast cancer and postoperative pain. Acta Anaesthesiol Scand 2003; 47: 26-9.

8. Liu SS, Wu CL. The effect of analgesic technique on postoperative patient-reported outcomes including analgesia: a systematic review. Anesth Analg 2007; 105: 789-808.

9. Carr E, Thomas V. Anticipating and experiencing postoperative pain: the patient's perspective. J Clin Nurs 1997; 6: 191-201.

10. Sjöling $M$, Nordahl G. Patient satisfaction with postoperative pain management in spite of experiences of high levels of pain. Eur Nurse 1998; 3: 264-73. 
11. Aouad MT, Kanazi GE, Malek K, Tamim H, Zahreddine L, Kaddoum RN. Predictors of postoperative pain and analgesic requirements following abdominal hysterectomy: an observational study. J Anesth 2016; 30: 72-9.

12. Ip Vivian HY, Abrishami A, Peng PW, Wong J, Chung F. Predictors of postoperative pain and analgesic consumption: a qualitative systematic review. Anesthesiology 2009; 111: 657-77.

13. Svensson I, Sjöström B, Haljamae H. Influence of expectations and actual pain experiences on satisfaction with postoperative pain management. Eur J Pain 2001; 5: 125-33.

14. Yücel A. Acute pain neurophysiology and the effect of postoperative pain on systems. PCA 1998: 4-24.

15. Kehlet $H$, Jensen TS, Woolf CJ. Persistent postsurgical pain: Risk factors and prevention. Lancet 2006; 367: 161825.

16. Bruce J, Thornton AJ, Powell R, Johnston M, Wells M, Heys SD, et al. Recovery Study Group. Psychological, surgical, and sociodemographic predictors of pain outcomes after breast cancer surgery: A population-based cohort study. Pain 2014; 155: 232-43.

17. Kaunisto MA, Jokela R, Tallgren $M$, Kambur O, Tikkanen $E$, Tasmuth $\mathrm{T}$, et al. Pain in 1,000 women treated for breast cancer: a prospective study of pain sensitivity and postoperative pain. Anesthesiology 2013; 119: 1410-21.

18. Roomruangwong C, Tangwongchai S, Chokchainon A. Preoperative anxiety among patients who were about to receive uterine dilatation and curettage. J Med Assoc Thai 2012; 95: 1344-51.

19. Mavridou P, Dimitriou V, Manataki A, Arnaoutoglou E, Papadopoulos G. Patient's anxiety and fear of anesthesia: effect of gender, age, education, and previous experience of anesthesia. A survey of 400 patients. J Anesth 2013; 27: 104-8.
20. Bruera E, Ripamonti C. Current status of patientcontrolled analgesia in cancer patients. Oncology (Williston Park) 1997; 11: 373-84.

21. Burgess C, Cornelius V, Love S, Graham J, Richards M, Ramirez A. Depression and anxiety in women with early breast cancer: five-year observational cohort study. BMJ 2005; 330: 702-5.

22. Tenenbaum G, Furst D, Weingarten G. A statistical reevaluation of the STAI anxiety questionnaire. J Clin Psychol 1985; 41: 239-44.

23. Özkan S. Psychiatric and Psychosocial Aspects of Cancer. Psychiatric Medicine: Counseling Liaison Psychiatry, 1994: s. 153-74.

24. Gul A, Ustundag H, Andsoy II, Kalkanli S. Anxiety and pain in surgically treated breast cancer patients. Asian Pac J Cancer Prev 2015; 16: 4261-4.

25. Robleda G, Sillero-Sillero A, Puig T, Gich I, Banos JE. Influence of preoperative emotional state on postoperative pain following orthopedic and trauma surgery. Rev Lat Am Enfermagem 2014; 22: 785-91.

26. Kain ZN, Sevarino FB, Rinder C, et al. Preoperative anxiolysis and postoperative recovery in women undergoing abdominal hysterectomy. Anesthesiology 2001; 94: 415-22.

27. Ali A, Altun D, Oguz BH, Ilhan M, Demircan F, Koltka K. The effect of preoperative anxiety on postoperative analgesia and anesthesia recovery in patients undergoing laparascopic cholecystectomy. J Anesth 2014; 28: 222-7.

28. Doering BG. Postoperative pain and psychological factors. Doctor J 2009; 94-6.

29. Momeni M, Crucitti M, De Kock M. Patient-controlled analgesia in the management of postoperative pain. Drugs 2006; 66: 2321-37. 